\title{
Khilafah Islam dalam Perspektif Sejarah Pemikiran Ali Abdul Raziq
}

\author{
Syahrudin Siregar \\ Dosen Prodi Sejarah Peradaban Islam UIN Sumatera Utara \\ syahrudin_iainsu@yahoo.co.id
}

\begin{abstract}
Ali Abdul Raziq is a scholar from Egypt. He was born in 1888. His famous thought is about khilafah. In his book, the title is al-Islam wa Usul al-Hukm: Bahs fi al-Khilafah wa al-Hukumah fi al-Islam, he argues that khilafah is not an obligation in Islam. It refers to the duty of the prophet Muhammad who is only obliged to convey Islam to people, not as king or leader of a State. This clearly makes many scholars deviate from his opinion. Therefore, it is important to discuss further related to the thought of Ali Abdul Raziq about the khilafah with the formulation of the problems, (1) Biography of Ali Abdul Raziq and (2) The thought of Ali Abdul Raziq about the khilafah. This study uses historical method with stages: heuristic, verification, interpretation, and historiography. The result of this research is that Ali Abdul Raziq through his book clearly states that the khilafah is not an obligation in Islam. This was influenced by the Western thoughts, he taked when he studied in England. This opinion ultimately resulted in him being ostracized among Egyptian scholars. Nevertheless, his thinking is widespread, as evidenced by the same pattern of thinking shared by several figures in Indonesia.
\end{abstract}

Keywords: Ali Abdul Raziq, Khilafah, History, Thought.

\begin{abstract}
Abstrak
Ali Abdul Raziq merupakan ulama yang berasal dari Mesir. Ulama yang dilahirkan pada tahun $1888 \mathrm{M}$ ini merupakan ulama yang terkenal dengan pandangannya mengenai khilafah. Dalam karyanya al-Islam wa Usul al-Hukm: Bahs fi al-Khilafah wa al Hukumah fi alIslam, ia berpendapat bahwa khilafah bukan merupakan suatu kewajiban dalam Islam. Hal tersebut merujuk kepada tugas nabi Muhammad yang hanya berkewajiban untuk menyampaikan Islam kepada umat manusia, bukan sebagai raja ataupun pemimpin dari suatu Negara. Hal ini jelas membuat banyak ulama bersimpang pendapat dengannya. Maka dari itu, penting kiranya membahas lebih lanjut terkait pemikiran Ali Abdul Raziq tentang khilafah dengan rumusan masalah, (1) Biografi Ali Abdul Raziq dan (2) Pemikiran Ali Abdul Raziq tentang khilafah. Penelitian ini menggunakan metode sejarah dengan tahap heuristik, verifikisai, interpretasi, dan historiografi. Adapun hasil dari penelitian ini adalah bahwa Ali Abdul Raziq melalui karyanya jelas menyatakan bahwa khilafah bukan merupakan kewajiban dalam Islam. Hal ini dipengaruhi oleh pemikiranpemikiran Barat yang ia peroleh saat ia menampuh pendidikannya di Inggris. Pendapat tersebut akhirnya mengakibatkan ia dikucilkan diantara ulama Mesir. Meskipun demikian, pemikirannya berkembang luas, terbukti dengan adanya corak pemikiran yang sama yang dianut oleh beberapa tokoh di Indonesia.
\end{abstract}

Kata kunci: Ali Abdul Raziq, Khilafah, Sejarah, Pemikiran. 


\section{PENDAHULUAN}

Para pemikir muslim berbeda pendapat mengenai ada atau tidaknya ajaran Islam tentang Negara atau juga hal-hal yang berkaitan dengan politik Islam. Ada dua istilah yang berkaitan erat dengan hal ini, yaitu khilafah dan imamah. Meskipun diambil dari sumber yang sama, yaitu Al-Quran, tetapi dalam praksis politik yang berkembang di dalam dunia Islam istilah ini dipakai oleh dua kelompok yang secara politik dianggap bersebrangan, yaitu Sunni dan Syi'ah.

Istilah Khilafahtullah fil ardl, muncul sejak kekuasaan Islam dikendalikan oleh Bani Umayyah dan Bani Abbasiyah. Menurut Azyumardi Azra, penggunaan istilah tersebut memiliki signifikasi dengan upaya absolutism kekuasaan. Sebab dengan demikian menunjukkan kekuasaan Bani Umayyah dan Bani Abbasiyah merupakan kekuasaan yang sah atau bahkan kekuasaan yang mutlak dan suci. ${ }^{1}$ Kata khilafah dalam bahasa Arab merupakan bentuk kata benda verbal yang mensyaratkan adanya subyek atau pelaku aktif yang biasa disebut dengan khalifah. Dengan demikian, kata khilafah menunjukkan kepada serangkaian tindakan yang dilakukan oleh khalifah itu sendiri. Oleh karena itu, tidak akan terwujud suatu khilafah tanpa kehadiran khalifah. ${ }^{2}$

Menurut Ganai, secara literal, khilafah berarti penggantian terhadap pendahulu, baik bersifat individual maupun kelompok. Sedangkan secara teknis, khilafah adalah lembaga pemerintahan Islam yang berlandaskan pada Al-Quran dan Al-Hadits. Khilafah merupakan medium untuk menegakkan addin (agama) dan memajukan syariah. ${ }^{3}$ Berdasarkan pandangan tersebut, maka muncullah suatu konsep yang menyatakan bahwa Islam meliputi din wa addaulah (agama dan Negara).

Kata khalifah itu sendiri berasal dari akar kata khalafa (kh-l-f), yang berarti menggantikan, mengikuti, atau yang datang kemudian. Bentuk jamak dari kata tersebut ada dua macam, yaitu khulafa ${ }^{4}$ dan khalaif5. Menurut Quraisyh Shihab, masing-masing makna dari kata tersebut mengiringi atau sesuai dengan konteksnya. Seperti misalnya ketika Allah menguraikan pengangkatan Nabi Adam as sebagai khalifah, digunakan kata tunggal, sebagaimana yang

${ }^{1}$ Muji Mulia, "Sejarah Sosial dan Pemikiran Politik Ali Abdul Raziq", dalam Jurnal Ilmiah Islam Futura", Vol. X, No. 2, Februari 2011, hlm. 120-121.

${ }^{2}$ Ade Shitu-Agbetola, "Theory of al-Khilafah in The Religio-Political View of Sayyid Qutb", dalam Hamdard Islamicus: Quartely Journal of Studies and Research in Islam, Vol. XIV, No. 2, Summer, 1991, hlm. 25.

${ }^{3}$ Ghulam Nabi Ganai, "Muslim Thinkers and Their Concept of Khalifah", dalam Hamdard Islamicus: Quartely Journal of Studies and Research in Islam, Vol. XXIV, No. 1, January-March 2001, hlm. 59.

${ }^{4}$ Misalnya penggunaan istilah Khulafa al-Rasyidin, sebutan untuk empat orang khalifah yang memerintah setelah Nabi Muhammaw saw, yaitu Abu Bakar, Umar ibn alKhattab, Usman ibn Affan, dan Ali ibn Abi Thalib (ditambah dengan adanya pendapat yang mengatakan bahwa Umar ibn 'Abdul Aziz, termasuk juga dalam kategori ini, ia menjadi anggota Khulafa al-Rasyidin yang kelima).

5"Dan Dia-lah yang menjadikan kamu penguasa-penguasa di bumi, dan Dia meninggikan sebagian kamu atas sebagian yang lain beberapa derajat..." (Q.S. Al-An'am: 165). 
tercantum dalam Q.S. Al-Baqoroh: 30. Sedangkan ketika pengangkatan Nabi Daud as digunakan bentuk jamak, sebagaimana yang tercantum dalam Q.S. Shad: 26.

Mereka telah melakukan penelitian terhadap ayat-ayat Alqur'an dan Sunnah Rasulullah SAW yang berkaitan dengan relasi (hubungan) Islam dengan Negara. Dari pengkajian mereka tersimpul dua kutub yang berseberangan. Pendapat pertama (mayoritas ulama), bahwa Islam memiliki ajaran yang berhubungan dengan Negara. Pendapat ini beralasan bahwa Nabi Muhammad SAW selain sebagai sebagai Nabi dan Rasul juga merangkap sebagai kepala Negara di Madinah, berikutnya setelah Rasulullah wafat, pemerintahan dilanjutkan oleh Abu Bakar Siddik r.a dan Khulafa ar- Rasyidin lainnya. Dan seterusnya dengan sistem negara khilafah. Tokoh yang berpendapat demikian antara lain adalah Rasyid Ridha dan sejumlah ulama AlAzhar Mesir. Alasan dari pendekatan sejarah tersebut dilengkapi dengan dalildalil berupa prinsip-prinsip Islam tentang politik. Dengan demikian umat Islam wajib mengikuti sistem kekhalifahan tersebut.

Pendapat kedua (minoritas ulama), bahwa Islam tidak memiliki ajaran tentang kenegaraan. Pendapat ini juga mengambil alasan melalui pendekatan historis bahwa Nabi Muhammad Saw. Hanyalah sebagai Rasulullah pembawa ajaran agama, tidak pernah menjadi kepala negara di Madinah dan tidak pernah menganjurkan pembentukan negara. Setelah Rasulullah Saw wafat digantikan oleh Abubakar R.a dan khalifah selanjutnya, tidak menggantikan tugas kenabian atau kerasulan, tapi hanya menggantikan kepemimpinan nabi di bidang keduniaan. Pendapat ini juga mengambil alasan dari ayat Alquran dan Sunnah yang mengkapling tugas kenabian tidak merangkap tugas keduniaan (termasuk politik). Karena itu negara sistem khalifah bukan dari ajaran agama dan tidak wajib dipertahankan, serta tidak ada halangannya membentuk negara model lain dari sistem khilafah. Pendapat ini antara lain dicetuskan oleh Ali Abdul Raziq (1888-1966).

Ali Abdul Raziq dipercaya sebagai ulama pertama yang menentang system khilafah. Ia dengan tegas membuat pambatas antara wilayatu al-Rasul dan wilayatu al-Hakim, wilayah ruhiyyah dan wilayah maddiyah, zu'ama' diniyyah dan zu'ama' siyasiyah, zu'ama' al-dakwah dan zu'ama' al-malik, tilka li al-din dan hadzihi li ad-dunya. Penentangan yang dilakukan oleh Abdul Raziq terhadap system khilafah ini mendapat angin segar ketika runtuhnya Khilafah Turki Ustmana padaawal abad ke-20 M. Sejarah mencatat bahwa Khilafah Turki Ustmani merupakan kerajaan Islam terakhir di dunia yang menerapkan system khilafah. Pasca keruntuhannya, Turki berubah menjadi sebuah Negara yang berbentuk republik. ${ }^{6}$

Ali Abdul Raziq dapat dikatakan sebagai seorang ulama yang cukup berani dalam mempertahankan argumennya terkait khilafah ini, terlebih lagi ketika ia mengatakan bahwa di dalam Islam tidak ada kewajiban untuk

'Luqman Rico Khashogi, "Telaah Atas Teori Pemerintahan Islam Ali Abd. Al-Raziq", dalam Rasail, Vol. 1, No. 1, 20014, hlm. 78. 
mendirikan Negara dalam bentuk khilafah. Ia juga berpendapat bahwa tugas Rasulallah hanya bersifat $u k h r o w i$, bukan bersifat duniawi. Dengan demikian, ia meyakini bahwa Rasul hanya sebagai utusan Tuhan yang bertugas untuk menyampaikan Islam kepada umat Islam. Pandangan-pandangan dan argument yang ia lontarkan ini kemudian menjadikan ia banyak dikecam dan bahkan "diblack list" dari jajaran ulama Mesir saat itu.

Ali Abdul Raziq tidak berhenti sampai pada argument itu saja, ia juga berani menafsirkan dalil-dalil Al-Quran yang dijadikan sebagai dasar atau landasakan untuk mendirikan khilafah dalam Islam oleh mayoritas ulama yang pro terhadap system khilafah. Salah satunya adalah kata ulil amr yang terdapat di dalam Q.S. An-Nisa: 26. Ali Abdul Razaq yang berkiblat kepada mufassir besar, seperti Baidhawi dan Zamakhsyari, berpendapat bahwa yang dimaksud dengan ulim amri di dalam ayat tersebut bukan khilafah atau imamah, melainkan sehabat nabi atau ulama. Lebih jauh, Abdul Raziq telah membantah bahwa nabi Muhammad saw telah mendirikan Negara Islam di Madinah. Jelaslah bahwa ia berpendapat jika Nabi Muhammad hanyalah Rasul Allah yang diutus untuk menyampaikan agam Islam, bukan sebagai kepala Negara maupun pemimpin politik di Negara Madinah.

Pemikiran Ali Abdul Razqi terkait khilafah secara mendalam ia tuangkan dalam karyanya yang berjudul al-Islam wa Ushul al-Hukm. Karya tersebut banyak mengundang tanggapan-tanggapan dari para ulama lainnya. Mayoritas dari tanggapan-tanggapan yang ia dapat berupa ketidak setujuan mayoritas ulama terhadap pemikiran dan karyanya tersebut. Meskipun demikian, sampai akhirat hayatnya ia tidak mengakui bahwa karya tersebut merupakan hasil buah tangannya sendiri. ${ }^{7}$ Bahkan seorang Maryam Jameela berpendapat bahwa karya tersebut merupakan hasil final dari atmoesfer yang suram, kental akan pesimisme, dan penyakit inferiority-complex (rendah diri) seorang muslim akibat penjajahan asing. ${ }^{8}$

Berdasarkan uraian-uraian di atas, maka dapat dilihat bahwa pemikiran Ali Abdul Raziq yang berkaitan dengan khilafah sangat unik dan menarik untuk diteliti lebih lanjut. Maka dari itu, tulisan ini akan memaparkan lebih jauh terkait Sejarah Pemikiran Ali Abdul Raziq terkait khilafah yang bertujuan untuk memaparkan lebih jauh terkait pemikiran Ali Abdul Raziq tentang Khilafah.

\section{HASIL DAN PEMBAHASAN}

\section{Biografi Ali Abdul Raziq}

Ali Abdul Raziq, merupakan seorang ulama yang dilahirkan pada tahun 1888 M, tepatnya di Provinsi al-Mania, di kota Bani Mizar, tepatnya di desa Abu Jirj. ${ }^{9}$

7Kamil Sa'fan, Kontroversi Khilafah dan Negara Islam: Tinjauan Kritis atas Pemikiran Ali Abdul Raziq, terj. Arif Chasanul Muna (Jakarta: Penerbit Erlangga, 2009), hlm. 71.

${ }^{8}$ Maryam Jameelah, Islam dan Modernisme, terj. A. Jainuri dan Syafiq A. Mughni (Surabaya: Usaha Nasional, 1982), hlm. 203.

'Kamil Sa'fan, Kontroversi Khilafah dan Negara Islam:..., hlm. 8. 
Ia wafat pada tanggal 22 September tahun $1966^{10}$ dalam usia 78 tahun. Ayahnya bernama Hasan ar-Raziq (w. 1907 M), seorang pemimpin berpengaruh besar di daerahnya yang merupakan aktivis politik serta wakil ketua Hizb al-Ummah (Partai Rakyat) pada tahun 1907. Hasan Abdul al-Raziq Pasha juga merupakan rekan politik Muhammad Abduh (1849-1915 M). Bersama rekannya tersebut mereka mendirikan Jam'iyyah al-Khairiyyah al-Islamiyyah. ${ }^{11}$ Ia juga memiliki hubungan erat dengan pemerintah kolonial Inggris. Partai ini dibentuk untuk menandingi Hizb al-Watan (Partai Kebangsaan).

Ali Abdul Raziq memulai pendidikannya di sebuah Kuttab di desa. Pada usia 10 tahun, di belajar di Lembaga Pendidikan al-Azhar pada Syekh Abmad Abu Khalwat yang merupakan sahabat dari Muhammad Abduh. ${ }^{12}$ Sebagaimana Muhammad Abduh, Syekh Abu Khalwat juga merupakan murid dari Syekh Jamaluddin al-Afghani ${ }^{13}$. Selama beberapa tahun ia mengikuti kuliah di Universitas Mesir (sekarang Universitas Cairo). Pada tahun 1910 (usia 22 tahun), dia mengikuti kuliah Sastra Arab di Universitas Cairo pada Prof. Naillino (ahli sastra dan syair Arab) dan sejarah filsafat pada Prof. Santillana (sejarah dan filsuf). Setelah memperoleh ijazah 'alimiyyah pada tahun 1911 dari Universitas al-Azhar, ia mulai bertugas memberikan kuliah di universitas tersebut.

Pada tahun 1912 (usia 24 tahun), beberapa bulan ia mengajar retorika di Universitas Al-Azhar. Pada tahun itu juga dia berangkat ke Inggris untuk melanjutkan studinya dalam ilmu ekonomi dan ilmu politik di Universitas Oxford. Selama belajar di Iggris, ia banyak membaca dan mempelajari teoriteori Barat, terutama teori-teori politik sebagai bidang kajiannya, di antaranya adalah Teori Politik Thommas Hobbes dan Jhon Locke. ${ }^{14}$ Pengetahuan dan pengalaman yang ia peroleh selama kuliah di Eropa, berhasil memberikan pengaruh besar terhadap pemikirannya, terutama dalam bidang rasionalitas

${ }^{10}$ M. Dihya' ad-Din ar-Rais, Islam dan Khilafah: Kritik Terhadap Buku Khilafah dan Pemerintahan dalam Islam, 'Ali Abdul Raziq, terj. Afif Mohammad (Bandung: Pustaka Pelajar, 1985), hlm. 5.

11Ibrahim Zaki Khusyid, Muqoddimah Karya Musthafa Abd. Al-Raziq dan Massignon, al-tasawwuf (Bairut: Dar al-Kitab al-Lubnaniy, 1984), hlm. 12

${ }^{12}$ Ensiklopedi Islam, editor Nina M. Armando (Jakarta: Ichtiar Baru Van Hoeve, 2005), hlm. 141.

13Syekh Jamaluddin al-Afghani (1839-1897 M), merupakan poitikus sekaligus pembaharu yang berasal dari Mesir. Ia berasal dari Afghanistan dan pernah tinggal India, Parsi, dan Mesir. Ia belajar di kota suci Najf dan Karbala, sehingga ada yang mengasumsikan bahw aia merupakan seorang penganut Syi'ah. Ia menolak melakukan pembaharuan di negeri-negeri yang bermadzhab Sunni, terutama dalam bidang politik. Lihat Said Jamaluddin al-Afghani, Pelopor Kebangkitan Muslim (Djakarta: Bulan Bintang, 1970), hlm. 23.

14Teori Hobbes menyatakan bahwa kekuasaan raja itu absolut, atau mutlak, dan tidak bertanggungjawab kepada siapa pun. Tetapi hanya yang absolut itu didapatkan melalui kontrak sosial. Sementara teori kontrak sosial John Locke adalah kontrak di antara raja dan rakyat, dengan adanya kontrak tersebut lahirlah hak dan kewajiban secara timbal balik. Rakyat menyerahkan hak-hak mereka termasuk kebebasan mereka kepada raja disertai sumpah setia untuk mematuhinya. Sebagai imbalan, raja menjanjikan bimbingan dan perlindungan serta pengelolaan Negara sebaik-baiknya. Adapun kontrak sosial versi Hobbes adalah suatu kontrak di antara sesama rakyat, dan raja tidak ikut serta bukan merupakan suatu pihak daripada kontrak tersebut, dia tidak terikat oleh perjanjian itu 
dalam berfikir, dan kebebasan dalam berpendapat, yang merupakan ciri khas dari peradaban Barat. Corak pemikiran inilah yang nantinya akan ia terapkan di Mesir, sekembalinya ia ke Mesir pada tahun 1914, tepatnya ketiak ia berusia 26 tahun. ${ }^{15}$

Pada tahun 1915 (usia 27 tahun), ia memulai karirnya di bidang pemerintahan sebagai seorang hakim di berbagai Mahkamah Syar'iyah (Pengadilan Agama) Mesir, antara lain di wilayah Iskandariyah, sekaligus sebagai menteri wakaf Mesir. Pada tahun yang sama ia juga mengajar sejarah Islam dan sastra Arab pada salah satu cabang Universitas al-Azhar yang ada di Iskandariyah. Sekitar tahun 1960 (usia 72 tahun), ia mengajar Sastra Arab pada Akademi Bahasa Arab, Mesir.

Pada waktu menjabat sebagai hakim di Iskandariyah, ia melakukan serangkaian penelitian tentang sejarah pradilan dan pemerintahan dalam Islam. Kemudian pada tahun 1925 (usia 37 tahun), hasil penelitiannya diterbitkan dalam sebuah buku berjudul: al-Islam wa Usul al-Hukm: Bahs fi al-Khilafah wa al Hukumah fi al-Islam (Islam dan Prinsip-prinsip pemerintahan: Satu Kajian tentang Kekhalifahan dan Pemerintahan dalam Islam). Buku inilah yang memperkenalkan Ali Abdul Raziq sebagai tokoh dalam bidang Fikih Siyasah. ${ }^{16}$

Abdul Raziq memiliki saudara bernama Mustafa Abdul Raziq yang pernah tinggal di Paris, dan pernah menjabat sebagai Rektor Al Azhar dari tahun 1945 sampai tahun 1947. Begitu pun, kehebatannya namun akhirnya Ali Abdul Raziq menjalani sisa hidupnya dengan ketidak-pastian. ${ }^{17} \mathrm{Hal}$ itu terjadi karena ia dikucilkan oleh para ulama di Mesir karena mempertahankan tulisan/ pemikirannya yang tertuang di dalam karyanya tersebut.

\section{Pemikiran Ali Abdul Raziq Tentang Khilafah}

Buku Ali Abdul Raziq berjudul al-Islam wa Usul al-Hukm itu setebal 103 halaman yang dia bagi ke pada tiga kitab dan masing-masing kitab terdiri dari tiga bab. Dalam bagian pertama (halaman 1-38) ia uraikan tentang definisi khilafah atau lembaga khalifah beserta ciri-ciri khususnya. Kemudian dipertanyakan tentang dasar anggapan bahwa mendirikan pemerintahan dengan pola khilafah itu merupakan suatu keharusan (agama), dan akhirnya dikemukakan bahwa baik dari segi agama maupun dari segi rasio, pola pemerintahan khilafah itu tidak perlu. Dalam bagian kedua (halaman 39-80) ia menguraikan tentang pemerintahan dalam Islam, tentang perbedaan antara risalah atau misi kenabian dengan pemerintahan, dan akhirnya disimpulkan bahwa risalah kenabian itu bukan pemerintahan dan bahwa agama itu bukan negara. Dalam bagian ketiga (halaman 81-103) ia menguraikan tentang khilafah atau lembaga khalifah dan pemerintahan dalam lembaga sejarah. Dalam hal ini

${ }^{15}$ Nasrun Haroen, dkk, Ensiklopedi Hukum Islam (Jakarta: PT. Ichtiar Baru Van Hoeve, 2000), hlm, 84.

${ }^{16}$ Ibid.

17Maryam Jamelah, Islam E Modernisme..., hlm.202 
Ali Abdul Raziq berusaha membedakan antara mana yang Islam dan mana yang Arab, serta mana yang agama dan mana yang politik. ${ }^{18}$

Fokus pemikiran Ali Abdul Raziq dalam mengklaim tidak adanya hubungan agama dengan politik (negara) terbagi kepada dua persoalan. Pertama, menyangkut kedudukan Nabi Muhammad Saw hanya sebagai Rasul Allah Swt, tidak berperan sebagai pemimpin negara (raja atau sultan). Menurutnya, umat Islam beranggapan bahwa Rasulullah Saw berhasil mendirikan negara baru di Madinah ("Negara Madinah”). Menurut mereka, Rasullulah Saw adalah segalanya bagi umat Islam, disamping pemimpin agama juga pemimpin negara. Tetapi menurutnya, Nabi Muhammad Saw hanyalah seorang utusan Allah Swt untuk menyampaikan risalah agama kepada umat tanpa bermaksud mendirikan sebuah negara. Nabi Muhammad Saw tidak mempunyai kekuasaan duniawi, negara atau pemerintahan. Tugasnya dalam mendirikan "Negara Madinah" tidak terlepas dari kepentingan kerasulannya. Nabi Saw tidak mendirikan pemerintahan dalam arti politik atau sesuatu yang mirip dengan kerajaan. Nabi Muhammad saw hanya seorang nabi seperti para nabi sebelumnya yang tidak pernah mengajak umatnya mendirikan sebuah negara atau pemerintahan. Ali Abdul Raziq menegaskan hal tersebut. ${ }^{19}$

Dia juga mengambil contoh Isa ibn Maryam sebagai Rasul bagi umat Nasrani, bukan raja. Buktinya Isa mengajak umat Kristen mengikut Kaisar, seperti dimuat oleh Injil: 22, ayat 21,Isa berkata: Taati Kaisar apa yang patut bagi Kaisar dan taati Allah apa yang patut bagi Allah. ${ }^{20}$

Dia menegaskan lagi, kita tidak pernah tahu dari sejarah kerasulan bahwa Allah Swt menyatukan fungsi kerasulan dan kerajaan. Kalaupun ada, sedikit. Dia bertanya, apakah Allah Swt menggabungkan fungsi rasul dan fungsi raja bagi Nabi Muhammad Saw, bukankah kerasulan lain dan kerajaan lain?

Ali Abdul Raziq mempertegas pendapatnya itu dengan mengutip berbagai ayat Al-Quran, antara lain surah al-Isra (17) ayat 54 (“... Dan kami tidaklah mengutusmu untuk menjadi penjaga bagi mereka"), surah al-Furqan (25) ayat 56 ("Dan tidaklah kami mengutus kamu melainkan hanya sebagai pembawa kabar gembira dan pemberi peringatan"), surah as-Syura (42) ayat 48 (“... Maka kami tidak mengutus kamu sebagai pengawas bagi mereka. Kewajibanmu tidak lain hanyalah menyampaikan risalah..."), dan surah alGhasyiyah (88) ayat 21-22 ("Maka berilah peringatan, karena sesungguhnya kamu hanyalah orang yang memberi peringatan. Kamu bukanlah orang yang berkuasa atas mereka").

Setelah mengutip puluhan ayat al-Quran, Ali Abdul Raziq menegaskan, dalil-dalil itu menunjukkan, tidak ada perbuatan nabi selain menyampaikan

\footnotetext{
${ }^{18}$ H. Munawir Sjadzali, Islam dan Tata Negara (Jakarta: UI-Press, 1990), hlm,139-140.

${ }^{19}$ Ali Abdul Raziq, Al-Islam wa Usul al- Hukm, Mesir, 1344. H/1925 M, hlm.49.

${ }^{20} \mathrm{Ibid} ., \mathrm{hlm} 4$.
} 
risalah Allah Swt kepada manusia, dan tidak ada tanggung jawabnya lagi dilaksanakan atau tidak tentang apa yang disampaikannya. ${ }^{21}$

Kedua, mengenai kekhalifahan. Menurut Ali Abdul Raziq, ada kepercayaan bahwa pola pemerintahan dalam Islam adalah sistem Khilafah dengan kekuasaan tertinggi dan mutlak pada seorang kepala negara/pemerintahan bergelar khalifah. Dia berfungsi sebagai pengganti Nabi Muhammad Saw dan berwenang mengatur kehidupan baik keagamaan maupun keduniaan, karena itu umat wajib menaatinya. ${ }^{22}$

Khalifah pertama setelah Rasullulah Saw wafat adalah Abu Bakar Siddiq r.a Dia juga cenderung mengaku sebagai pengganti nabi dan melarang sebutan kepada dirinya sebagai khalifah Allah. Abu Bakar Siddiq r.a menyatakan:23 Singkatnya para ulama muslim berpendapat khalifah adalah pengganti Rasullulah:24 Tetapi Ali Abdul Raziq berpendapat lain. Katanya, jika Abu Bakar r.a sebagai pengganti Muhammad Saw, sedangkan Rasullullah Saw adalah khalifatullah, maka Abu Bakar r.a harus menjadi khalifatullah. Namun Abu Bakar r.a marah dipanggil khalifatullah. ${ }^{25}$

Berkenaan dengan pendapat Muhammad Rasyid Rida, bahwa mendirikan lembaga khilafah adalah wajib (hukumnya) bagi umat Islam, Ali Abdul Raziq menyatakan, sama sekali tidak menemukan dasar kuat yang mendukung bahwa hukum mendirikan lembaga khilafah adalah wajib, baik dalam Al-Quran, sunnah, maupun ijmak (consensus ulama). ${ }^{26}$ Rasyid Rida mendasarkan kewajiban umat Islam untuk mendirikan lembaga khilafah pada surah an-Nisa (4) ayat 59, yang mewajibkan ketaatan kepada ulil amri setelah ketaatan kepada Allah SWT dan Rasul-Nya. Hal ini tidak dapat diterima oleh Ali Abdul Raziq. Menurut pengertian Ali Abdul Raziq, ulil amri adalah para tokoh umat Islam yang hidup pada masa Nabi Saw dan masa sesudahnya, yakni para khalifah, hakim, komandan pasukan perang, dan para pemuka agama. Menurutnya, ayat yang mewajibkan taat kepada ulil amri ini tidak dapat dijadikan alasan kewajiban mendirikan lembaga khilafah.

Kemudian hadis Nabi Saw yang menyatakan bahwa pemimpin umat itu berasal dari suku Quraisy (al-A'immah min Quraisy) dan yang telah membaiat (sumpah setia) kepadanya wajib mematuhinya kecuali dalam soal kemaksiatan (HR. al-Bukhari dan Muslim), menurutnya juga tidak sesuai dijadikan alasan kewajiban mendirikan lembaga khilafah.

Menurut Ali Abdul Raziq, tidak ada larangan agama bagi kaum muslimin untuk berlomba dengan bangsa lain dalam bidang ilmu sosial maupun ilmu politik. Kaum muslimin bebas meninggalkan sistem lama (khilafah), dan merekayasa kaidah-kaidah kekuasaan dan aturan-aturan negara

${ }^{21}$ Ibid., hlm 73.

${ }^{22}$ Ibid., hlm.2.

23Ibid., hlm 3.

${ }^{24}$ Ibid., hlm 11.

${ }^{25}$ Ibid., hlm 96.

26Ibid., hlm 16-17. 
(modern) yang sesuai kebutuhan, sesuai pengalaman bangsa lain (negara maju di Barat). ${ }^{27}$

Pemikiran Ali Abdul Raziq ini mengemuka pada saat umat Islam sedang dihebohkan oleh tindakan Mustafa Kemal Ataturk (1881-1938); Presiden pertama Turki setelah negara itu menjadi Republik yang menghapuskan lembaga khilafah (Usmaniyah) pada bulan Februari 1924.

Seolah-olah buku Ali Abdul Raziq yang terbit tahun 1925 itu, menyambut dan mengukuhkan penghapusan negara sistem khilafah yang diklaim oleh umumnya ulama sebagai negara model Islam. Tokoh seperti Muhammad Rasyid Ridha pada waktu itu bersama tokoh dan ulama lain dari al-Azhar sedang mempersiapkan Muktamar Akbar Islam (Kongres) di Kairo dalam rangka cita-cita menghidupkan kembali sistem khilafah di dunia Islam. Saham Rasyid Ridha cukup besar menentang Ali Abdul Raziq yang berakhir pada pengucilannya dari Majelis Ulama. ${ }^{28}$

Muhammad Umarah (ahli hukum Mesir) dalam bukunya yang berjudul al-Islam wal Ushul al Hukm li Ali Abdul Raziq (Islam dan prinsip-prinsip pemerintahan menurut Ali Abdul Raziq) memberikan komentar bahwa buku karangan Ali Abdul Raziq paling banyak mendapat sorotan dan kritik dari para ulama Mesir, bahkan beliau dituduh oleh ulama Mesir sebagai kafir zindik, makanya dalam rapat majelis ulama besar al-Azhar pada tanggal 12 Agustus 1925 yang dihadiri 24 ulama diputuskan bahwa isi buku dari Ali Abdul Raziq tersebut bertolak belakang dengan ajaran Islam. Pendapat itu tidak pantas keluar dari seorang muslim apalagi dari seorang ulama. Hasil rapat ulama besar al-Azhar itu juga memutuskan pemecatannya sebagai hakim dan larangan untuk menduduki jabatan pemerintahan. ${ }^{29}$

Pada bulan Mei 1926 para ulama Mesir yang dipimpin oleh Rektor alAzhar Mesir melangsungkan Kongres Khalifah dengan keputusan, sistem khalifah adalah bagian integral Islam, tetapi institusi itu tidak mungkin dilaksanakan kecuali pada saat yang tepat, dan seorang khalifah kelak akan dipilih oleh dewan perwakilan umat Islam. ${ }^{30}$

Ulama Mesir demikian keras menyudutkan Ali Abdul Raziq dan pemikirannya, namun dia tetap dalam pendiriannya. Ketika ditanya para peserta pada sidang majelis Ulama Mesir apakah Ali Abdul Raziq sanggup membagi agama Islam itu atas dua bagian dan melepaskan hukum-hukum agama yang berkenaan dengan urusan keduniaan dari agama itu sendiri. Artinya melepaskan sebagian ayat-ayat Quran dan Sunnah Rasul dikeluarkan dari ajaran Islam. Dia menjawab, sekali-kali dia tidak pernah berkata demikian, tidak dalam kitabnya dan tidak pernah mengeluarkan ucapan menyerupai atau mirip dengan itu. Dia juga mengungkapkan bahwa Nabi telah membawa

\footnotetext{
27Ibid., hlm 103.

${ }^{28}$ Munawir Sjadzali, Islam dan Tata Negara..., hlm.139.

${ }^{29}$ Nasrun Haroen, Ensiklopedi Hukum Islam..., hlm 85.

30Maryam Jamelah, Islam dan Modernisme..., hlm.203.
} 
kaedah-kaedah dan hukum-hukum yang umum yang amat banyak berkenaan dengan urusan perikehidupan dan urusan-urusan umat. ${ }^{31}$

Pemikir Islam wanita turunan Yahudi, Margaret Marcus (Maryam Jamelah) dari Lahore mencap Ali Abdul Raziq sebagai orang yang dipengaruhi Kristen. Sebenarnya, sejak semula Islam ditujukan menjadi sebuah gerakan umat dengan masyarakat berpadu di bawah kepemimpinan yang terorganisasi. Ajaran-ajaran Islam yang utama seperti zakat, jihad bahkan shalat berjamaah dan sejumlah larangan yang tidak bisa dilaksanakan tanpa kekuatan politik adalah bukti dan kesaksian yang tidak bisa dibantah. Ali Abdul Raziq dan para pendukungnya di Barat lebih senang jika Islam itu semata-mata teologi, filsafat teoritis atau impian kosong yang tidak perlu diimplementasikan. Sekurangkurangnya mereka bermaksud melemahkan umat Islam. ${ }^{32}$

Pemikiran Ali Abdul Razqi ini terus berkembang, bahkan sampai ke Indonesia. Hal itu terbukti saat terjadi polemik antara M. Natsir dan Ir. Soekarno pada tahun 40-an berkenaan dengan penerapan hukum Islam di Indonesia. Soekarno (Presiden pertama RI) sebagai orang nasionalis, berpendapat agama tidak perlu diurus negara dan dia mendukung sikap Kemal Pasja Cs dengan merujuk pendapat Ali Abdul Raziq tentang terpisahnya urusan agama dan negara. Natsir menuduh Soekarno tidak mampu membaca buku Ali Abdul Raziq secara langsung karena tidak mampu berbahasa Arab. Soekarno hanya membaca 4 sampai 5 baris terjamahan Le Mode Islamique karangan Max Mejerhof. Menurut Natsir tidak satu baris pun dari 103 halaman buku Ali Abdul Raziq yang bisa dijadikan sebagai penguat atau pembela perbuatan Kemal Pasja di Turki. ${ }^{33}$

Munawir Sjadzali juga menuduh Ali Abdul Raziq tidak konsisten dalam beberapa hal. Misalnya mengakui Nabi banyak bertindak sebagai kepala negara namun tidak mengikuti pola tertentu dan baku. Itu berarti bukan tidak ada pemerintahan, cuma berjalan sederhana sesuai zamannya. Kemudian, soal ucapan Isa ibn Maryam, Ali Abdul Raziq lupa bahwa umat Al Masih waktu itu sedang terjajah penguasa asing dan penganut kepercayaan yang berbeda. Ali Abdul Raziq juga lupa bahwa sekali orang masuk Islam berlaku kepadanya segala peraturan dalam Islam yang disebut Syari'ah bersumber pada wahyu. Untuk menjamin berlakunya aturan itu diperlukan penguasa untuk memaksa aturan tersebut atas mereka yang hendak menolaknya. Itulah yang dilakukan Nabi. ${ }^{34}$

Pro dan kontra tentang relasi Islam dengan negara di kalangan pemikir Islam Indonesia juga terjadi belakangan ini. KH. Abdulrahman Wahid (Gus Dur) disadari atau tidak merupakan salah seorang pendukung Ali Abdul Raziq. "Dia boleh dikatakan mengikuti aliran pemikiran, kadang-kadang disebut sebagai liberal Islam, Ali Abdul Raziq, cendekiawan agama muda dari

${ }^{31}$ M. Natsir, Capita Selecta, cet. Ketiga (Jakarta: Bulan Bintang, 1973), hlm 485.

${ }^{32}$ Maryam Jamelah, Islam dan Modernisme..., hlm.207.

${ }^{33} \mathrm{Ibid}$., hlm. 481-482.

${ }^{34}$ Munawir Sjadzali, Islam dan Tata Negara..., hlm, 143-144. 
Mesir... Ada tiga pilar pemikiran Abdulrahman Wahid. (1) Islam harus secara aktif dan subtansif ditafsirkan ulang atau dirumuskan ulang agar tanggap terhadap tuntutan kehidupan modern, (2) dalam konteks Indonesia, Islam tidak boleh menjadi agama negara, dan (3) Islam harus menjadi kekuatan yang inklusif demokratis dan pluralis, bukan ideologi negara yang eksklusif. ${ }^{35}$

Senada atau mungkin pengikut Ali Abdul Raziq, adalah Nurcholish Madjid (Cak Nur). Dia berpendapat, perkataan negara Islam tidak dikenal dalam sejarah. Buktinya Nabi dimakamkan tiga hari setelah meninggal. Kejadian ini disebabkan karena penggantiannya tak jelas, pola suksesi tidak jelas. Itu menunjukkan masalah kenegaraan tidak menjadi bagian integral dari Islam. Munculnya gagasan negara Islam atau Islam sebagai negara tak lain merupakan bentuk kecenderungan apologetis. ${ }^{36}$

Dalam memandang relasi Islam dan negara, pandangan Amien Rais sangat berbeda dengan Cak Nur dan Gus Dur (sebagai Kamalistein atau Raziqiyah Indonesia). Menurut Amien, Islam telah memberikan etik yang terlalu jelas bagi pengelolaan seluruh kehidupan manusia, termasuk kehidupan bernegara dan berpemerintahan. Islam merupakan ajaran utuh yang tidak mengenal dikotomi. Amien menolak pendapat Ali Abdul Raziq. ${ }^{37}$ Terlepas dari pro dan kontra itu, sampai sekarang Ali Abdul Raziq diakui oleh dunia sebagai tokoh pembaharu Islam atau pemikir modern Islam. ${ }^{38}$

Dasar perbedaan pemikiran Ali Abdul Raziq dengan ulama lain terletak pada pemahaman bersatu atau tidaknya fungsi kerasulan Nabi Muhammad Saw dalam hal menangani hubungan manusia secara vertikal dengan Allah Swt, dan hubungan manusia secara horizontal dengan manusia serta dengan alam dan isinya. Pihak Ali Abdul Raziq mendikotomikan antara dua urusan tersebut, sedangkan pihak kontranya menyatukan fungsi kerasulan tersebut.

Meskipun telah mendapat kecaman dari berbagai pihak, sebenarnya pemikiran Ali Abdul Raziq dapat dirasionalkan sebagai berikut:

1. Pemikiran beliau bahwa fungsi Nabi Muhammad Saw hanya sebagai pemimpin keagamaan mendukung fungsi Islam sebagai agama Rahmatan Lil Alamin yang wajib disebarkan ke selutuh penjuru dunia. Jika Nabi Muhammad Saw selain sebagai pemimpin agama juga sekaligus sebagai pemimpin Negara Madinah, maka agama yang

\footnotetext{
35Jhon L. Osposito-Jhon O.Voll, Tokoh-Kunci Gerakan Islam kontemporer, terj. Sugeng Haryanto, dkk (Jakarta: PT. RajaGrapindo Persada, 2002), hlm.264.

${ }^{36}$ Dedy Djamaluddin Malik, dkk, Zaman Baru Islam Indonesia: Pemikiran dan Aksi Politik (Bandung: Zaman Wacana Mulia, 1998), hlm. 168.

${ }^{37}$ Ibid., hlm.171.

38Jhon J. Donohue, Islam Dan Pembaharuan: Ensiklopedi Masalah-Masalah, terj. Machnun Husein (Jakarta: PT. RajaGrapindo Persada, 1995), hlm,39-54.; Harun Nasution, Pembaharuan dalam Islam cet. Ke.12 (Jakarta: Bulan Bintang, 1996), hlm 84-85.; Abdul Sani, Lintas Sejarah Pemikiran, Perkembangan Modern dalam Islam (Jakarta: RajaGrapindo Persada, 1998) .hlm.76-77.; Busthomi Muhammad Said, Pembaharu dan Pembaharuan dalam Islam (Ponorogo: PSIA, 1992), hlm.150-153.; Suadi putro, Muhammad Arkoun Tentang Islam Modernitas (Jakarta: Paramidana, 1998), hlm,2-3.
} 
dibawanya hanya untuk Negara Madinah, dan mungkin ditambah kota Makkah setelah hijrah. Ternyata semasa dan setelah wafatnya beliau sampai sekarang agama Islam didakwahkan oleh umat Islam ke seluruh dunia.

2. Pemahaman Ali Abdul Raziq dianggap mendikhotomikan urusan agama dan urusan Negara, sebenarnya, pemikiran itu membebaskan kewajiban pemimpin Islam di kemudian hari yang tidak mampu mengemban sebagai pemimpin agama sekaligus sebagai pemimpin Negara. Jika dwi fungsi kepemimpinan menjadi wajib, maka mayoritas pemimpin akan melanggar kewajiban karena tidak mampu menjalankan kepemimpinannya. Sedangkan dalil untuk mewajibkan kepemimpinan dwi fungsi itu sekaligus tidak ditemukan baik secara langsung maupun secara kias.

3. Bahwa jika urusan agama dan Negara dipisahkan maka urusan agama dapat dijalankan tanpa urusan Negara dan urusan Negara tanpa urusan agama juga dapat berjalan. Sebaliknya, jika urusan agama dan Negara wajib disatukan, maka urusan agama tidak dapat dijalankan tanpa urusan Negara, dan urusan Negara tidak dapat dijalankan tanpa urusan agama. Artinya agama Islam wajib di Negara Islam, dan Negara Islam wajib pada agama Islam. Ternyata, banyak Negara yang berjalan dan berkembang tanpa mengurus agama Islam, dan agama Islam berkembang di Negara yang tidak mengurus agama.

\section{PENUTUP}

Dari uraian di atas dapat disimpulkan sebagai berikut:

1. Masalah ada tidaknya relasi Islam dengan negara akan tetap menjadi perdebatan panjang, mungkin sampai hari kiamat, sebagaimana terjadi selama ini pro dan kontra pemikiran Ali Abdul Raziq karena cara pandang terhadap fungsi Kerasulan Nabi Muhammad Saw dalam koridor yang berbeda.

2. Masalah ini terjadi karena nash Al-Quran dan arahan Rasulullah Saw tidak secara tegas memerintahkan pembentukan negara. Nash yang ada hanya memuat prinsip-prinsip yang umum, dapat diberlakukan untuk segala bentuk kenegaraan atau urusan lain, kapan dan dimana saja.

3. Terlepas dari pro-kontra mengenai masalah ini, yang dibutuhkan dewasa ini adalah keberanian dan kemampuan umat Islam mendirikan negaranya sendiri. Apakah Republik, kerajaan, kesultanan, khilafah atau apapun namanya. Negara itu akan lahir pasti tidak akan sama dengan bentuk masa lalu karena dipengaruhi oleh keadaan sekarang. 


\section{REFERENCE}

Abdul Sani, Lintas Sejarah Pemikiran, Perkembangan Modern Dalam Islam. Raja Grapindo Persada, Jakarta, 1998.

Al-Afghani, Said Jamaluddin. Pelopor Kebangkitan Muslim. Djakarta: Bulan Bintang, 1970.

Ar-Rais, M. Dihya' ad-Din. Islam dan Khilafah: Kritik Terhadap Buku Khilafah dan Pemerintahan dalam Islam, 'Ali Abdul Raziq, terj. Afif Mohammad. Bandung: Pustaka Pelajar, 1985.

Donohue, Jhon J. Islam Dan Pembaharuan: Ensiklopedi Masalah-Masalah, terj. Machnun Husein. Jakarta: PT. Raja Grapindo Persada, 1995.

Ensiklopedi Islam, editor Nina M. Armando. Jakarta: Ichtiar Baru Van Hoeve, 2005.

Ganai, Ghulam Nabi. "Muslim Thinkers and Their Concept of Khalifah". Dalam Hamdard Islamicus: Quartely Journal of Studies and Research in Islam. Vol. XXIV. No. 1. January-March, 2001.

Haroen, Nasrun, dkk. Ensiklopedi Hukum Islam. Jakarta: PT. Ichtiar Baru Van Hoeve, 2000.

Jameelah, Maryam. Islam dan Modernisme, terj. A. Jainuri dan Syafiq A. Mughni. Surabaya: Usaha Nasional, 1982.

Khashogi, Luqman Rico. “Telaah Atas Teori Pemerintahan Islam Ali Abd. AlRaziq". Dalam Rasail. Vol. 1. No. 1, 20014.

Khusyid, Ibrahim Zaki. Muqoddimah Karya Musthafa Abd. Al-Raziq dan Massignon, al-tasawwuf. Bairut: Dar al-Kitab al-Lubnaniy, 1984.

Malik, Dedy Djamaluddin, dkk. Zaman Baru Islam Indonesia: Pemikiran dan Aksi Politik. Bandung: Zaman Wacana Mulia, 1998.

Muji Mulia. "Sejarah Sosial dan Pemikiran Politik Ali Abdul Raziq". Dalam Jurnal Ilmiah Islam Futura. Vol. X. No. 2, Februari 2011.

Nasution, Harun. Pembaharuan dalam Islam cet. Ke.12. Jakarta: Bulan Bintang, 1996.

Natsir, M. Capita Selecta, cet. Ketiga. Jakarta: Bulan Bintang, 1973.

Osposito, Jhon L. Dan Jhon O.Voll. Tokoh Kunci Gerakan Islam kontemporer, terj. Sugeng Haryanto, dkk. Jakarta: PT. RajaGrapindo Persada, 2002.

Putro, Suadi Putro. Muhammad Arkoun Tentang Islam Modernitas. Jakarta: Paramidana, 1998.

Sa'fan, Kamil. Kontroversi Khilafah dan Negara Islam: Tinjauan Kritis atas Pemikiran Ali Abdul Raziq, terj. Arif Chasanul Muna. Jakarta: Penerbit Erlangga, 2009. 
Sani, Abdul. Lintas Sejarah Pemikiran, Perkembangan Modern dalam Islam. Jakarta: RajaGrapindo Persada, 1998). Said, Busthomi Muhammad. Pembaharu dan Pembaharuan dalam Islam. Ponorogo: PSIA, 1992.

Shitu, Agbetola, Ade. "Theory of al-Khilafah in The Religio-Political View of Sayyid Qutb". Dalam Hamdard Islamicus: Quartely Journal of Studies and Research in Islam. Vol. XIV. No. 2. Summer, 199.

Sjadzali, H. Munawir. Islam dan Tata Negara. Jakarta: UI-Press, 1990. 